\title{
Procedure for Handling 4-H Accounts: Guidelines for Fund-Raising
}

Marilyn Norman and Joy C. Jordan²

\section{Guidelines for 4-H Fund-Raising}

All 4-H units should prepare an annual program budget to establish allocation of financial resources to fulfill program needs. To support a wide variety of 4-H programs, the volunteer organizations must raise private funds. Corporate and individual donors are more likely to support groups that they know or that are visible in the community. Groups looking for additional funding should:

- Develop a viable plan for the use of the funds.

- Develop a reputation within the community for organizational and fiscal responsibility.

- Ask for donations of money.

All methods of fund-raising by $4-\mathrm{H}$ units are subject to the provisions outlined in this fact sheet. All other individuals and organizations wishing to raise funds for 4-H must obtain the approval of the County Extension Director or the Director of Cooperative Extension or designee before they can use the 4-H Name and Emblem to solicit funds.

Authorization to use the 4-H Name and Emblem is the responsibility of the Program Leader for 4-H Youth Programs working in cooperation with each District Director, County Director, or designee, who is then responsible for authorizing the use of the 4-H Name and Emblem within her or his jurisdiction. All methods of fund-raising must comply with the general fund development guidelines. District and County Directors are responsible for reviewing fund-raising activities and assuring their compliance with applicable policies.

Funds raised by 4-H units must comply with the following basic principles:

- Any raising or use of funds by a unit must be to further the research and educational goals of $4-\mathrm{H}$.

- A membership fee or dues cannot be a requirement for enrollment in the 4-H Youth Development Program in Florida. However, insurance costs and other charges incidental to program participation may be required to defer the costs for specific programs or activities.

- All fund-raising activities in support of the 4H Youth Development Program must conform to the following regulations:

1) Fund-raising activities for cash or goods and services must conform with applicable federal and state laws and local ordinances.

\footnotetext{
${ }^{1}$ This document is $4 \mathrm{H} 5.5$, one of a series of the Florida 4-H Program, Florida Cooperative Extension Service, Institute of Food and Agricultural Sciences, University of Florida. Published February 2007. Please visit the 4-H Website at http://4h.ifas.ufl.edu/Curriculum/index.htm.

2

2 Marilyn Norman, Associate Professor in the Department of Family, Youth and Community Sciences and State 4-H Program Leader, and Joy C. Jordan, Associate Professor in the Department of Family, Youth and Community Sciences, Institute of Food and Agricultural Sciences, University of Florida, Gainesville.
} 
2) Federal laws regarding the use of the 4$\mathrm{H}$ name also apply in these activities. Pertinent federal rules and regulations governing the use of the 4-H Name and Emblem, as published in the Federal Register, March 17, 1987, must be followed.

\section{What is "Quid Pro Quo" and What is Its Relationship to Fund-Raising Events?}

Quid pro quo (kwīd' prō kwō') is an equal exchange or substitution. Quid means "something," prō means "for," and quō, as an ablative of quid, means "something."

So, "quid pro quo" is a payment made partly as a contribution and partly for goods and services provided to the donor by a charity.

An example of a quid pro quo contribution is when the donor pays a charity $\$ 100$ to attend a dinner event. The market value for the food and entertainment is $\$ 40$. This amount is not what the charity pays for the food and entertainment, but rather the market value of those items. Accordingly, $\$ 60$ of this $\$ 100$ would be a taxdeductible gift. For another example, think of a case where a donor is promised a specific item in exchange for a gift - e.g., for a $\$ 100$ contribution, the donor will receive a $\$ 25$ alumni directory. This will result in a $\$ 75$ gift.

\section{Gift and Endowment Funds}

4-H clubs or units may seek and receive gifts or funds for a variety of things, including events, activities, long-term support, or gifts in memory/honor of a special person. When these gifts are small ( $\$ 100$ or less), the club may coordinate the process locally. The County Extension Office should be involved with larger gifts and with donors who are requesting a documenting letter for tax benefit.

- In general, the donated funds are classified as gifts when the following characteristics exist:

The intent is to make a charitable contribution;

$>$ The donor does not impose contractual requirements;
$>$ The funds are awarded irrevocably.

- An endowment fund is a fund whose donor has stipulated that the fund principal must remain intact (inviolate) and that only the interest income from the donor's gift may be expended.

- Any proposals of significant gifts, gifts given with restrictions, or gifts proposed as endowments, unless governed by a specific Memorandum of Understanding, must be reviewed by the County Director.

- Gifts and endowments may be given directly to the University of Florida Foundation by private individuals, groups, agencies, or foundations for 4-H. These funds may be restricted to the county $4-\mathrm{H}$ programs of the donor's choice.

- Both gift and endowment funds may be earmarked for specific purposes (e.g., an electric project, a dog project guide, $4-\mathrm{H}$ scholarships), but are administered by Cooperative Extension in accordance with university policies and procedures.

\section{Grants as a Source of Program Funds}

It is essential to understand grants and their purposes. A grant is money given in return for action promised. The grantor agrees to give a specified amount on the condition that the money will be used for a designated purpose.

Grants are one-time donations to start a specific project or program. Most grants are given with the assumption that after a project or program is started, funds from other sources will be available to continue the program. Very few grants are renewable, especially those given by private organizations or foundations. When you consider the time invested, it is often more profitable to pursue renewable resources than grant money. However, grants can play a vital role in initiating new programs or helping to maintain a current program for a short period of time until more permanent funding can be obtained. If grant funding seems to be the most practical way to initiate a program or project, do not hesitate to pursue the opportunity. 
In order to enhance your 4-H program's chances of receiving support, you will want to make sure that:

- The 4-H program has closely matched the project or program to be funded with the foundation's areas of interest.

- The 4-H program is a 501(c)(3) tax-exempt nonprofit organization. This is required, with few exceptions. This means that the EIN is registered with the IRS.

- The 4-H program, or its leadership, has a good record and enjoys strong support from its constituencies.

- The 4-H program is able to demonstrate on paper its expertise, experience, and ability to carry out a project.

- The 4-H program follows sound management practices, including standard budgeting and accounting practices, and has an active and broadly representative advisory council.

\section{Criteria for Accepting Funds}

The following criteria should be used in determining the acceptance and administration of funds.

- Federal and state funds allocated by the U.S. Department of Agriculture (USDA) and the state of Florida to support the 4-H Youth Development Program will be managed by the university in accordance with state and federal policies.

- The County Board of Commissioners of each cooperating county provides, under the permissive authority granted by the state legislature, for the local maintenance and operation of Cooperative Extension work in that county. All expenditures are made in accordance with county fiscal procedures.

- Grants or contracts from federal, state, or other external agencies for applied research projects and training or demonstration projects must be processed and administered by the University Contracts and Grants Office. 4-H units may not commit themselves or the university to any contractual obligations.

- External funds supporting action, training, demonstration, or applied research projects in which an agent has principal investigator or project director status must be processed through the university Contracts and Grants Coordinator and administered by the District Director, regardless of the source.

\section{Guidelines for Accepting Gifts of Property, Equipment, or Animals}

Individuals and/or groups may also wish to provide an outright donation of property, equipment, or animals to 4-H units. Several guidelines will be helpful in these situations.

- Property and equipment may be accepted by a unit volunteer or faculty member on behalf of the 4-H program of the University of Florida.

- The intent of the gift should be for the educational purposes of the group of youth or volunteers. It is inappropriate for 4-H or Extension to accept a gift with the understanding that it is to benefit a single person.

- If the donor requests documentation of the gift for tax purposes, the issuing unit may do so on letterhead paper, using the EIN that has been registered with the IRS. The value of the property or equipment should not be listed in the letter.

- The property or gift remains a part of the 4-H or Extension program until expended or unusable, and must be documented in the unit financial records.

- Due to IRS regulations surrounding donated animals, it is not recommended (for tax purposes) to accept the donation of any live animal.

\section{Raffles and Games of Chance}

The USDA has a long-standing policy discouraging fund-raising activities involving raffles, lotteries, games of chance, etc. There are several reasons. First, federal regulations for the 
Guidelines for the Authorized Use of the 4-H

Name and Emblem state that fund-raising

programs using the 4-H Name and Emblem

should be carried out for specific educational

purposes. Second, private support monies

should be a) given and used for

priority educational purposes, and b) accounted

for efficiently.

Additionally, the 4-H Name and Emblem may not be used on or associated with products and services sold in connection with $4-\mathrm{H}$ fundraising programs where an endorsement of a commercial firm, product, or service is either intended or effected.

\section{Resources}

\section{IFAS Publications:}

Grant for Contract Handling for County Offices: http://imm.ifas.ufl.edu/6_40/640-13.htm

\section{USDA 4-H Fact Sheets:}

http://www.national4-hheadquarters.gov/library/ 